\title{
Antibody response against 26 and 46 kilodalton released proteins of yersinia in yersinia triggered reactive arthritis
}

Outi Mäki-Ikola, Matthias Pulz, Jürgen Heesemann, Riitta Lahesmaa, Riitta Saario, Auli Toivanen, Kaisa Granfors

\begin{abstract}
Using an inhibition enzyme linked immunosorbent assay (ELISA) the serum antibody responses against released proteins of yersinia of molecular weights 26 and 46 kilodaltons were studied in 37 patients with and in 21 patients without reactive arthritis following yersinia infection. Although no difference was seen for the $\mathbf{4 6}$ kilodalton released protein, patients with yersinia triggered reactive arthritis had higher levels of antibodies against the 26 kilodalton released protein at the beginning of the disease than patients with uncomplicated yersiniosis. This may indicate an increased production of this protein in the early infection leading to poorer phagocytosis of the bacteria and thereby to the persistence of yersinia organisms within the arthritic host.
\end{abstract}

(Ann Rheum Dis 1992; 51: 1247-1249)

Reactive arthritis develops as a complication following certain infections including those caused by yersiniae and salmonellae. In the development of reactive arthritis host-microbe interaction is important, but the exact pathogenetic mechanisms of arthritis are largely unknown. ${ }^{12}$

Human pathogenetic strains of the genus Yersinia possess closely related plasmids that control virulence functions. ${ }^{3}$ Several plasmid encoded proteins have been identified as outer membrane proteins or as secreted proteins (released proteins, RP1 to RP5). ${ }^{4}$ These released proteins are expressed in vivo, as patients and animals produce antibodies against them during yersinia infection. ${ }^{6-10}$

Patients who develop reactive arthritis after yersinia or salmonella infection show several contrasting features of the immune response compared with those who do not develop arthritis. ${ }^{12}$ For example, the patients with arthritis show an especially strong and persisting serum antibody response against the pathogen. Analysing the immune response against the whole cell lysate of a plasmid bearing strain of yersinia by immunoblotting, an examination of single bands does not show any difference between the patients with and without arthritis. ${ }^{11}$ Testing the immune response against released proteins, however, showed that patients with yersinia triggered reactive arthritis more often have antibodies against the 36 kilodalton released protein. ${ }^{9}$ Using a quantitative enzyme linked immunosorbent assay (ELISA) the total amount of IgA class antibodies against the released proteins is significantly higher in patients with arthritis. ${ }^{10}$
In this study we have further investigated the role of released proteins in the pathogenesis of reactive arthritis. We evaluated the antibody levels against two single released proteins-that is, those of 26 and 46 kilodaltons, in serum samples from patients with and without reactive arthritis following yersinia infection with an inhibition ELISA using monoclonal antibodies directed against the two proteins.

\section{Patients and methods}

\section{PATIENTS AND SERUM SAMPLES}

The levels of antibodies to released protein were measured in a total of 127 serum samples from 58 patients with a sporadic Yersinia enterocolitica $0: 3$ infection from our collection of patients with yersiniosis. Diagnosis of the patients was based on the typical clinical picture (diarrhoea, abdominal pain, vomiting, and/or arthritis) and clearly increased levels of antibodies to yersinia detected by ELISA ${ }^{12}$ in 22 patients the pathogen was also isolated from the stools. The age of the patients ranged from 16 to 62 years (mean 35), and the female to male ratio was $25: 33$. Of the patients 21 had recovered uneventfully from the infection, and 37 had developed typical reactive arthritis (verified by a rheumatologist) as a complication within three weeks of the onset of infection. Of the 34 patients with arthritis tested, 29 were positive for the HLA-B27 antigen; the corresponding figure for 20 patients without arthritis was three. Serum samples obtained at different follow up times were stored at $-20^{\circ} \mathrm{C}$ and studied simultaneously.

\section{PREPARATION OF RELEASED PROTEINS}

The plasmid positive strain of $Y$ enterocolitica O:3 (strain Y-108) was grown as the source of released proteins, and released proteins were prepared as described previously. ${ }^{4}$

\section{MONOCLONAL ANTIBODIES}

The monoclonal antibody 9-200 recognising the 46 kilodalton released protein of $Y$ enterocolitica O:3 has been described previously. ${ }^{6}$ The monoclonal antibody PU-174 was produced equally and recognises the 26 kilodalton released protein of $Y$ enterocolitica $0: 3$. The analysis of the monoclonal antibodies by sodium dodecylsulphate polyacrylamide gel electrophoresis and immunoblotting was performed as described previously (figure) ${ }^{6}$ Hybridoma culture supernatants were used. The isotype of 9-200 was IgGl and that of PU-174 was IgG2b. 


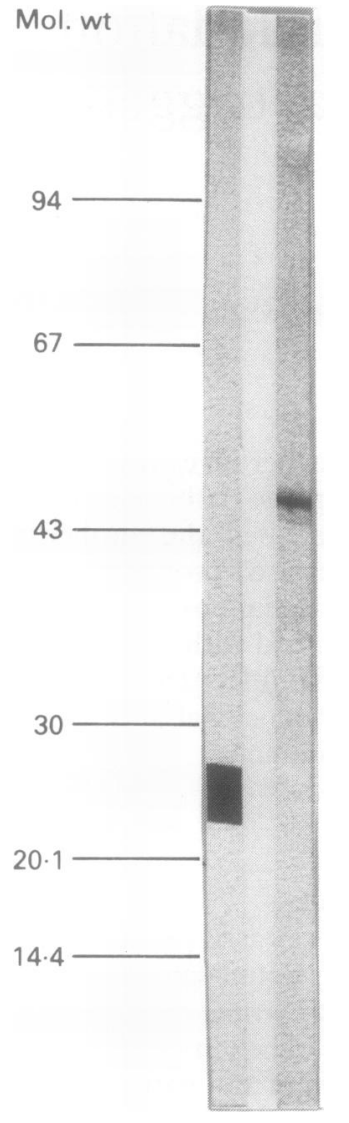

Sodium dodecylsulphate/ polyacrylamide gel electrophoresis and immunoblotting analysis of monoclonal antibodies using released proteins from Yersinia enterocolitica as antigen. Monoclonal antibody $P U-174$ recognises the 26 kilodalton released protein and monoclonal antibody 9-200 the 46 kilodalton released protein.
INHIBITION ELISA WITH MONOCLONAL ANTIBODIES

The procedure was similar to that described previously. ${ }^{12}$ Polystyrene microtitre plates (Costar, Cambridge, MA, USA) were coated with the optimum concentration of released proteins $(6 \mu \mathrm{g} / \mathrm{ml})$ in phosphate buffered saline (PBS) and saturated with $1 \%$ bovine serum albumin in PBS (1\% BSA-PBS). Serum samples were diluted $1: 10$ in $1 \%$ BSA-PBS and incubated on the plates $(75 \mu \mathrm{l} /$ well $)$ for two hours at $37^{\circ} \mathrm{C}$. After washing $60 \mu \mathrm{l}$ of the monoclonal antibody (9-200 at 1:50 and PU-174 at 1:2000 dilution) was added to incubate overnight at room temperature. After washing $60 \mu \mathrm{l}$ of goat alkaline phosphatase conjugated antiserum (absorbed with human serum) specific for mouse IgG and IgM (TAGO, Burlingame, CA, USA) was added at a dilution of 1:4000 and incubated for three hours at $37^{\circ} \mathrm{C}$. Quantitation by enzyme substrate was performed as described previously. ${ }^{12}$ Results were compared with values obtained by the monoclonal antibody alone (without serum sample) to calculate the inhibition percentage according to the following formula $(\mathrm{OD}=$ optical density):

Inhibition $\%=\left[\left(O D_{c}-O D_{B}\right)-\left(O D_{x}-O D_{B}\right)\right] /\left(\left(O D_{C}-O D_{B}\right)\right] \times 100 \%$ where $O D_{C}$ is the value of the uninhibited control obtained with the monoclonal antibody alone, $\mathrm{OD}_{\mathrm{B}}$ is the background of the test obtained with the buffer, and $\mathrm{OD}_{\mathrm{x}}$ is absorbance obtained by the patient's serum sample.

\section{Results}

Consecutive samples from 58 patients with $Y$ enterocolitica $0: 3$ infection were studied in the inhibition ELISA. Serum samples from patients were used to inhibit the binding of monoclonal antibodies to 46 and 26 kilodalton released proteins. The table shows the inhibition percentages obtained with samples collected on three occasions during follow up. The 1:10 dilutions of serum samples from patients with arthritis were able to inhibit the binding of 26 kilodalton released protein specific monoclonal antibody by $40 \%$ in the beginning of the disease, compared with $20 \%$ for serum samples from patients without arthritis $(p<0.05)$; this means that there were more antibodies to the monoclonal antibody PU-174 defined epitope of the 26 kilodalton released protein in the serum samples of patients with arthritis. The tendency of the serum samples from patients with arthritis to inhibit the binding of the 26 kilodalton released protein specific monoclonal antibody more than serum samples from patients without arthritis was also seen at follow up, but the difference was not statistically significant.

There were no differences in the ability to inhibit the binding of the $\mathbf{4 6}$ kilodalton released protein specific monoclonal antibody between the two patient groups at any follow up time.

\section{Discussion}

In this study we used an inhibition ELISA to measure quantitatively the antibody responses against monoclonal antibody defined epitopes of two released proteins of plasmid bearing $Y$ enterocolitica in patients with a recent yersinia infection. It has been shown that at the beginning of the disease the antibody response against all released proteins together is higher in patients who developed reactive arthritis as a complication after infection compared with those with uncomplicated yersiniosis. ${ }^{10}$ Little is known, however, about the immune response against single released proteins. In this study we could show that at least the 26 kilodalton released protein, also called the yersinia outer membrane protein 5 (Yop5), ${ }^{13}$ participates in this strong antibody response to released proteins. Patients with yersinia triggered reactive arthritis had higher antibody levels against this protein than patients with uncomplicated yersinia infection. Using the qualitative immunoblotting method it was shown previously that patients with arthritis develop antibodies against the 36 kilodalton released protein more often. ${ }^{9}$ The 26 and 36 kilodalton released proteins have been shown to be the most immunogenic released proteins. ${ }^{8} 9$

The plasmid encoded released proteins, especially Yop5, are known to increase the ability of yersinia to resist opsonisation and phagocytosis by granulocytes. ${ }^{13} 14$ Thus the stronger antibody response to the 26 kilodalton released protein in patients with arthritis may indicate increased production of this protein, which in turn may lead to inhibition of phagocytosis of the bacteria. This phenomenon, together with the initially weak IgM class antibody and cell mediated immune responses to yersinia in patients with arthritis, may lead to failure in the first line of defence against the microbe, and thereby to long term persistence of the pathogen within the host. ${ }^{1}$ This agrees with our observations of the persistence of microbe specific antibodies in patients with arthritis for long periods after the initial infection. ${ }^{12}$ The antibody response against the 26

Inhibition of the binding of monoclonal antibodies to released proteins by serum samples from patients with Yersinia enterocolitica $0: 3$ infection with or without reactive arthritis

\begin{tabular}{|c|c|c|c|c|}
\hline \multirow{2}{*}{$\begin{array}{l}\text { Time after onset } \\
\text { of infection (months) } \\
\text { (No of patients } \\
\text { with/without arthritis) }\end{array}$} & \multicolumn{2}{|c|}{$\begin{array}{l}\text { Monoclonal antibody } 9-200 \text { (specificity } \\
46 \text { kilodalton released protein) }\end{array}$} & \multicolumn{2}{|c|}{$\begin{array}{l}\text { Monoclonal antibody PU-174 (specificity } \\
26 \text { kilodalton released protein) }\end{array}$} \\
\hline & $\begin{array}{l}\text { Mean (SD) percentage } \\
\text { inhibition in patients } \\
\text { with/without } \\
\text { reactive arthritis: }\end{array}$ & $\begin{array}{l}\text { Percentage of patients } \\
\text { with/without arthritis } \\
\text { with significant } \\
\text { inhibitiont }\end{array}$ & $\begin{array}{l}\text { Mean }(S D) \text { percentage } \\
\text { inhibition in patients } \\
\text { with/without } \\
\text { reactive arthritis* }\end{array}$ & $\begin{array}{l}\text { Percentage of patients } \\
\text { with/without arthritis } \\
\text { with significant } \\
\text { inhibitiont }\end{array}$ \\
\hline $\begin{array}{l}1-2(n=36 / 21) \\
6-8(n=21 / 18) \\
12-16(n=18 / 13)\end{array}$ & $\begin{array}{l}60.7(26.0) / 52.3(30.6) \\
42.6(27.0) / 37.8(26.1) \\
32.5(29.7) / 39.6(16.6)\end{array}$ & $\begin{array}{l}47 \cdot 2 / 42 \cdot 8 \\
23 \cdot 8 / 11 \cdot 1 \\
11 \cdot 1 / 7 \cdot 7\end{array}$ & $\begin{array}{l}40 \cdot 2(35 \cdot 0) \ddagger / 20 \cdot 3(32 \cdot 0) \\
31 \cdot 9(29 \cdot 0) / 20 \cdot 1(25 \cdot 5) \\
28 \cdot 4(29 \cdot 1) / 13 \cdot 7(22 \cdot 3)\end{array}$ & $\begin{array}{l}52 \cdot 89 / 23 \cdot 8 \\
47 \cdot 6 / 22 \cdot 2 \\
38 \cdot 9 / 23 \cdot 1\end{array}$ \\
\hline
\end{tabular}

*Level of inhibition for healthy blood donors is about $30 \%$ for monoclonal antibody $9-200$ and $10 \%$ for PU-174.

+ Percentage inhibition $>$ mean +2 SD in control subjects.

p $<0.05$ when values for patients with and without arthritis are compared using $\ddagger$ Student's $t$ test or $\$ \chi^{2}$ tests. 
kilodalton released protein in patients with and without arthritis differed only at the beginning of the disease. It seems that the released proteins are functionally important only for the bacteria invading tissues and trying to escape the host's defence mechanisms-that is, at the early stage of the infection, as suggested previously. ${ }^{10}$ Thus, the stronger antibody response against the 26 kilodalton released protein may simply indicate a greater challenge by bacterial antigens reflecting greater invasion in patients with arthritis.

Hoogkamp-Korstanje et al stressed the importance of the 46 kilodalton released protein in the pathogenesis of chronic yersinia infection, as they showed yersinia bacilli in intestinal biopsy specimens of patients with chronic yersinia triggered reactive arthritis by immunofluorescence using monospecific rabbit antiserum to this protein. ${ }^{15}$ In this study, however, no evidence for the involvement of the 46 kilodalton released protein in the pathogenesis of reactive arthritis was found.

In conclusion, the 26 kilodalton released protein and the antibody response against it may contribute to the abnormal host-microbe interaction in patients developing yersinia triggered reactive arthritis. This may lead to ineffective elimination of the pathogen and thereby to the persistence of bacterial antigens in the joints. ${ }^{12}$

We thank Dr Rauli Leino and Dr Riitta Merilahti-Palo for some of the patient records and samples. Mrs Soile Niittoaho is acknowledged for her excellent technical assistance. This work was supported by the Finnish Cultural Foundation, the Rheumawas supported by the Finnish Cultural Foundation, the Rheuma-
tism Research Foundation, the Alfred Kordelin Foundation, the tism Research Foundation, the Alfred Kordelin Foundation, the
Turku University Foundation, the Paulo Foundation, the Finnish Academy and the Sigrid Jusélius Foundation.
1 Granfors $\mathrm{K}$. Do bacterial antigens cause reactive arthritis? Rheum Dis Clin North Am 1992; 18: 37-48.

2 Mäki-Ikola $\mathrm{O}$, Granfors $\mathrm{K}$. Salmonella-triggered reactive arthritis. Lancet 1992; 339: 1096-8.

3 Cornelis G R, Biot T, Lambert de Rouvroit C, et al. The Yersinia yop regulon. Mol Microbiol 1989; 3: 1455-9.

4 Heesemann J, Gross U, Schmidt N, Laufs R. Immunochemical analysis of plasmid-encoded proteins released by enteropathogenic Yersinia sp. grown in calcium-deficient media. Infect Immun 1986; 54: 561-7.

5 Michiels T, Wattiau P, Brasseur R, Ruysschaert J-M Cornelis G. Secretion of Yop proteins by Yersiniae. Infect Immun 1990; 58: 2840-9.

6 Heesemann J, Kalthoff H, Koch F. Monoclonal antibodies directed against plasmid-encoded released proteins of enteropathogenic Yersinia. FEMS Microbiol Lett 1986; 36 : $15-9$.

7 Heesemann J, Schröder J, Ulrich M. Analysis of the classspecific immune response to Yersinia enterocolitica virulence-associated antigens in oro-gastrically infected vabbits. Microbial Pathogen 1988; 5: 437-47.

8 Stăhlberg T H, Tertti R, Wolf-Watz H, Granfors K, Toivanen A. Antibody response in Yersinia pseudotuberculosis III infection: analysis of an outbreak. $\mathcal{F}$ Infect Dis 1987; 156: 388-91.

9 Stăhlberg T H, Heesemann J, Granfors $\mathrm{K}$, Toivanen A. Immunoblot analysis of IgM, IgG and IgA responses to plasmid encoded released proteins of Yersinia enterocolitica in patients with or without Yersinia triggered reactive arthritis. Ann Rheum Dis 1989; 48: 577-81.

10 Lahesmaa-Rantala R, Heesemann J, Lehtonen O-P, Granfors $K$, Toivanen A. Avidity of antibodies against released proteins of Yersnia spp: comparison of patients with proteins of Yersnia spp: comparison of patients with or without

11 Stăhlberg T H, Granfors $\mathrm{K}$, Toivanen A. Immunoblot analysis of human IgM, IgG and IgA responses to plasmidencoded antigens of Yersinia ent
Med Microbiol 1987; 23: 157-63.

12 Granfors K, Ogasawara M, Hill J L, Lahesmaa-Rantala R, Toivanen A, Yu D T Y. Analysis of IgA antibodies to lipopolysaccharide in Yersinia-triggered reactive arthritis. $\mathcal{J}$ Infect Dis 1989; 159: 1142-7.

13 Forsberg $\AA$, Wolf-Watz H. Genetic analysis of the yopE region of Yersinia spp.: identification of a novel conserved locus, yerA, regulating yopE expression. 7 Bacteriol 1990 172: 1547-55.

14 Tertti R, Eerola E, Lehtonen O-P, Stăhlberg T H, Viander $M$, Toivanen A. Virulence-plasmid is associated with the inhibition of opsonization in Yersinia enterocolitica and Yersinia pseudotuberculosis. Clin Exp Immunol 1987; 68: 266-74.

15 Hoogkamp-Korstanje J A A, de Koning J, Heesmann J. Persistence of Yersinia enterocolitica in man. Infection 1988; 16: 81-5. 